\title{
INFESTASI KECACINGAN DENGAN KADAR HEMOGLOBIN PADA ANAK DIPESISIR PANTAI DUSUN SERIWE DESA SERIWE
}

\author{
Dina Nurmayani ${ }^{1}$, Fitria Ernawati ${ }^{2}$, Miftahul Jannah ${ }^{3}$ \\ ${ }^{1-3}$ Mahasiswa Jurusan Analis Kesehatan, Poltekkes Kemenkes Mataram, Indonesia
}

\section{Article Info}

Article history:

Received Mei $10^{\text {th }}, 2019$

Revised Jun $24^{\text {th }}, 2019$

Accepted Jul 19 $9^{\text {th }}, 2019$

\section{Keyword:}

Hemoglobin

helminthiasis infection

\begin{abstract}
Worm infestation in children on the coast of Seriwe Village has never been examined. This infestation of helminthiasis can cause a decrease in hemoglobin levels because the worms can absorb nutrients and blood in the body needed for the formation of $\mathrm{Hb}$. This worm is a disease that is environmentally based and can be reduced if the surrounding community has a clean and healthy lifestyle such as hand washing. As it is known that the cleanliness of the coastal environment in Seriwe Hamlet is still relatively low. However, the examination of worms has never been done in the coastal area of Seriwe Hamlet. Therefore it is necessary to examine Hb in children in the coastal areas of Seriwe Hamlet who are suspected of being infected with worms. Objective to knowing the investment in worms with hemoglobin levels in children on the coast of Seriwe Village. Methods this research is an analytic analytic research that is trying to explore how and why health phenomena occur. A total of 49 respondents were examined for hemoglobin levels and their feces. This was done to see the relationship between investment in worms and hemoglobin levels. Results the average hemoglobin level in children on the coast of Seriwe village in Seriwe village is $11.0 \mathrm{gr} /$ $d l$. Of the 49 faecal samples, 18 faecal samples were positive for helminthiasis. Conclusions : Occurs decreased levels of $\mathrm{Hb}$ in infections helminthiasis
\end{abstract}

Copyright @ Jurnal Analis Medika Bio Sains All rights reserved.

\section{ABSTRAK}

Kecacingan ini merupakan penyakit yang berbasis lingkungan dan dapat dikurangi jika masyarakat sekitar berperilaku hidup bersih dan sehat seperti cuci tangan. Seperti yang diketahui bahwa kebersihan lingkungan pesisir pantai di Dusun Seriwe masih tergolong rendah. Namun pemeriksaan kecacingan belum pernah di lakukan di wilayah pesisir pantai Dusun Seriwe. Oleh karena itu perlu dilakukan pemeriksaan Hb pada anak-anak di wilayah pesisir pantai Dusun Seriwe yang terduga terinfeksi kecacingan. Mengetahui investasi kecacingan dengan kadar hemoglobin pada anak dipesisir pantai Desa Seriwe. Penelitian ini bersifat analitik obsevasional yaitu penelitian yang mencoba menggali bagaimana dan mengapa fenomena kesehatan itu terjadi. Sebanyak 49 responden diperiksa kadar hemoglobin dan fesesnya hal tersebut dilakukan untuk melihat hubungan antara investasi kecacingan dengan kadar hemoglobin. Rata-rata kadar hemoglobin pada anak di pesisir pantai dusun seriwe desa seriwe adalah 11,0 gr/dl. Dari 49 sampel feses, sebanyak 18 sampel feses yang positif kecacingan. Terjadi penurunan kadar Hemoglobin pada infeksi kecacingan

Kata Kunci : Hemoglobin, Infeksi Kecacingan 


\section{Pendahuluan}

Kasus kecacingan pada anak-anak di Kabupaten Lombok Timur tergolong masih tinggi. Kecacingan ini menjadi salah satu penyebab stunting pada balita di LombokTimur. Berdasarkan data stunting di Puskesmas Masbagik, sebanyak 5 balita mengalami stunting diikuti juga oleh infeksi kecacingan. Berdasarkan data riskesdas tahun 2013 prilaku higienis yang meliputi kebiasaan atau prilaku BAB sebesar $73,3 \%$ sedangkan prilaku benar dalam mencuci tangan terbilang rendah yaitu sebesar 39,3\% (Riskesdas, 2013).

Kecacingan mempengaruhi asupan (intake), pencernaan, penyerapan, dan metabolisme makanan. Selain dapat menghambat perkembangan fisik, kecerdasan dan produktifitas kerja, dapat menurunkan ketahanan tubuh sehingga mudah terkena penyakit lainnya, salah satunya adalah anemia. Kadar Hb mengalami penurunan pada orang yang terinfeksi Soil Transmitted Helminth (STH) karena kelompok cacing tersebut dapat menyerap nutrisi dan darah pada tubuh yang dibutuhkan untuk pembentukan $\mathrm{Hb}$.

Anak-anak yang tinggal di pesisir pantai umumnya memiliki ,perilaku hidup bersih dan sehat yang kurang baik, hal ini disebabkan karena sangat jarang dilakukan penyuluhan kesehatan PHBS di pesisir pantai, disebabkan juga oleh kondisi ekonomi dan tingkat pendidikan disana terbilang masih rendah. Data mengenai hubungan antara infestasi kecacingan dengan kadar hemoglobin pada anak di pesisir pantai Dusun Seriwe Desa Seriwe belum pernah dilaporkan oleh sebab itu sanagat perlu dilakukan penenlitian mengenai "Infestasi Kecacingan Dengan Kadar Hemoglobin Pada Anak di Pesisir Pantai Dusun Seriwe Desa Seriwe. Tujuan penelitian ini adalah mengetahui infestasi kecacingan dengan kadar hemoglobin pada anak di pesisir pantai Desa Seriwe.

\section{Metode Penelitian}

Penelitian ini bersifat analitik observasional. Keadaan yang di gambarkan secara objektif dalam penelitian ini ialah investasi kecacingan dengan kadar hemoglobin pada anak di di pesisir pantai Dusun Seriwe Desa Seriwe. Pengambilan sampel dalam penelitian ini adalah Simple Random Sampling. Besar sampel yang digunakan dalam penelitian ini adalah sebanyak 49 sampel. Pertama sampel darah diperiksa kadar $\mathrm{Hb}$ nya terlebih dahulu kemudia dilakukan pemeriksaan feses pada sampel yang memiliki kadar $\mathrm{Hb}$ dibawah normal. Kemudian data hasil pemeriksaan dianalisis secara deskriptif.

\section{Hasil Penelitian dan Pembahasan}

Pemeriksaan kadar hemoglobin dilakukan menggunakan sampel darah kapiler pada 49 anakanak di Dusun Seriwe, Desa Seriwe. Sedangkan pemeriksaan kecacingan yang dilakukan pada sampel feses menggunakan metode langsung. Hasil pemeriksaan kadar hemoglobin dapat dilihat pada tabel. Tabel 4.1. Hasil pemeriksaan infeksi kecacingan (Positif) dan Hb pada anak-anak di Dusun Seriwe, Desa Seriwe.

\begin{tabular}{cccl}
\hline No. & Kode sampel & Kadar Hb & Jenis Cacing \\
\hline 1 & 3 & 10,0 & Ancylostoma duodenale \\
\hline 2 & 8 & 9,7 & Ancylostoma duodenale \\
\hline 3 & 13 & 9,5 & Trichuris trichiura \\
\hline 4 & 14 & 10,9 & Trichuris trichiura \\
\hline 5 & 15 & 8,9 & Trichuris trichiura \\
\hline 6 & 19 & 10,0 & Ascaris lumbricoides \\
\hline 7 & 20 & 10,9 & Ancylostoma duodenale \\
\hline 8 & 26 & 8,8 & Trichuris trichiura \\
\hline 9 & 27 & 10,0 & Ascaris lumbricoides \\
\hline 10 & 28 & 9,2 & Trichuris trichiura \\
\hline 11 & 29 & 9,4 & Ascaris lumbricoides \\
\hline 12 & 30 & 10,1 & Trichuris trichiura \\
\hline 13 & 34 & 10,2 & Trichuris trichiura \\
\hline 14 & 36 & 9,3 & Ascaris lumbricoides \\
\hline 15 & 37 & 10,2 & Trichuris trichiura
\end{tabular}


Jurnal Analis Medika Bio Sains

Vol.6, No.2, September 2019, pp. 135 139

ISSN: 2656-2456 (Online)

ISSN: 2356-4075 (Print)

\begin{tabular}{cccl}
16 & 38 & 10,6 & Ascaris lumbricoides \\
\hline 17 & 40 & 8,9 & Trichuris trichiura \\
\hline 18 & 41 & 10,8 & Trichuris trichiura \\
\hline Persentase & $36,73 \%$ & & \\
\hline $\begin{array}{c}\text { Rerata } \\
\text { kadar } \mathrm{Hb}\end{array}$ & & 9,9 & \\
\hline
\end{tabular}

Berdasarkan tabel 4.1 menunjukkan bahwa sebanyak 18 sampel yang positif terinfeksi kecacingan dengan persentase sebesar 36,73\%. Rerata kadar Hb sampel yang positif terinfeksi kecacingan yaitu 9,9 g/dl. Dari 18 sampel, sebanyak 3 sampel feses terinfeksi cacing Ancylostoma duodenale, 10 sampel feses terinfeksi cacing Trichuris trichiura, dan sebanyak 5 sampel terinfeksi cacing Ascaris Lumbricoides. 
Tabel 4.2. Hasil pemeriksaan infeksi kecacingan (Negatif) dan Hb pada anak-anak di Dusun Seriwe, Desa Seriwe

\begin{tabular}{|c|c|c|}
\hline No. & Kode sampel & Kadar $\mathrm{Hb}$ \\
\hline 1 & 1 & 13,3 \\
\hline 2 & 2 & 11,8 \\
\hline 3 & 4 & 12,0 \\
\hline 4 & 5 & 12,6 \\
\hline 5 & 6 & 12,0 \\
\hline 6 & 7 & 13,7 \\
\hline 7 & 9 & 11,2 \\
\hline 8 & 10 & 13,0 \\
\hline 9 & 11 & 11,7 \\
\hline 10 & 12 & 12,4 \\
\hline 11 & 16 & 12,2 \\
\hline 12 & 17 & 13,0 \\
\hline 13 & 18 & 11,0 \\
\hline 14 & 21 & 12,6 \\
\hline 15 & 22 & 11,6 \\
\hline 16 & 23 & 11,9 \\
\hline 17 & 24 & 12,3 \\
\hline 18 & 25 & 12,0 \\
\hline 19 & 31 & 12,0 \\
\hline 20 & 32 & 11,0 \\
\hline 21 & 33 & 13,4 \\
\hline 22 & 35 & 10,9 \\
\hline 23 & 39 & 11,8 \\
\hline 24 & 42 & 11,8 \\
\hline 25 & 43 & 13,0 \\
\hline 26 & 44 & 12,1 \\
\hline 27 & 45 & 12,6 \\
\hline 28 & 46 & 11,4 \\
\hline 29 & 47 & 11,6 \\
\hline 30 & 48 & 12,3 \\
\hline 31 & 49 & 10,1 \\
\hline Persentase & $63,27 \%$ & \\
\hline Rerata kadar $\mathrm{Hb}$ & & 12,1 \\
\hline
\end{tabular}


Berdasarkan tabel 4.2 menunjukkan bahwa dari 49 sampel darah dan feses yang diperiksa, sebanyak 31 sampel feses tidak terinfeksi kecacingan dengan persentase sebesar 63,27\% dan rerata kadar Hb yaitu 12,1 gr/dl.

\section{Pembahasan}

Hasil pemeriksaan kadar hemoglobin $(\mathrm{Hb})$ pada anak-anak dari 49 sampel darah yang diperiksa, sebanyak 20 sampel darah yang mengalami anemia $(\mathrm{Hb}<11)$. Dari 20 sampel tersebut, hanya 18 sampel feses yang positif terinfeksi telur Ancylostoma duodenale (cacing tambang), Ascaris lumbricoides (cacing gelang), Trichuris trichiura (cacing cambuk).

Menurut hasil penelitian Ibrahim ( 2013) yang menyatakan bahwa tidak ada hubungan antara status Soil Transmitted Helminth dengan kejadian anemia pada murid SD Inpres Bakung Samata Gowa, yang berarti bahwa bukan hanya satu faktor yang menyebabkan terjadinya anemia namun banyak faktor yang menjadi penyebab terjadinya anemia. Seperti diketahui bersama bahwa anemia tidak hanya disebabkan oleh satu faktor saja, namun banyak faktor yang mempengaruhi terjadinya anemia, yaitu Perdarahan eksternal maupun internal.

Anak-anak yang tinggal di pesisir pantai umumnya memiliki prilaku hidup bersih dan sehat yang kurang baik, hal ini disebabkan karena sangat jarang dilakukan penyuluhan kesehatan PHBS di pesisir pantai, disebabkan juga oleh kondisi ekonomi dan tingkat pendidikan disana terbilang masih rendah. Salah satunya adalah anak-anak yang tinggal di pesisir pantai Dusun Seriwe Desa Seriwe Kecamatan Jerowaru, Kabupaten Lombok Timur. Infeksi ini dipengaruhi oleh kondisi lingkungan serta tingkat ekonomi masyarakat disekitar sana. Penyebab yang sama juga dapat terjadi di daerah pesisir pantai karena pembangunan ekonomi belum merata. Pembangunan rumah serta peningkatan kualitas hidup juga masih rendah. Hal tersebut dapat menjadi salah satu penyebab maraknya infeksi kecacingan pada anak-anak di pesisir pantai, yang dapat menyebabkan kadar Hemoglobin rendah dan terjadi kasus anemia.

Syahnuddin dkk (2017) dalam penelitiannya menyatakan bahwa kejadian kecacingan pada seluruh responden remaja putri di beberapa SLTA Kota Palu sebesar 11,1\%. Dari hasil ini juga diketahui bahwa tidak ada hubungan antara anemia dan kecacingan.

Berdasarkan hasil penelitian Basalamah dkk (2013) Dari hasil penelitian yang dilaksanakan Proporsi infeksi cacing pada anak SD GMIM Buha Manado dalam populasi penelitian ini adalah 14 anak (17,5\%) dan tidak terinfeksi 66 anak (82,5\%). Anak yang terinfeksi cacing berjumlah 14 anak, 9 anak diantaranya memiliki kadar hemoglobin yang normal ( $\geq 11,5 \mathrm{~g} / \mathrm{dl}$ ), sedangkan 5 anak memiliki kadar hemoglobin kurang normal hingga mencapai 9,5 g/dl.Terdapat hubungan yang positif antara infeksi cacing dengankadar Hb anak. Dimana anak yang terinfeksi cacing pada akhirnya akan mengalami kadar hemoglobin yang rendah

\section{Kesimpulan}

Berdasarkan hasil penelitian yang telah dilakukan dapat disimpulkan bahwa terjadi penurunan kadar hemoglobin pada infestasi kecacingan.

\section{Daftar Pustaka}

1. Ibrahim, I. A. (2014) 'Status Kecacingan Soil Transmitted Helminth (STH) Dalam Pemantauan Kejadian Anemia Pada Murid SD Inpres Bakung Samata Kabupaten Gowa Tahun 2013',

2. Riskesdas (2013) 'Riset Kesehatan Dasar Kementerian RI', Proceedings, Annual Meeting - Air Pollution Control Association, 6. doi: 1 Desember 2013.

3. Syahnuddin Muchlis (2017) Hubungan Anemia Gizi dengan Infeksi Kecacingan pada Remaja Putri di Beberapa SLTA di Kota Palu. 